\title{
Work organisation, basic materials, tools and devices used in old Korčula's (Croatia) wooden shipbuilding
}

\author{
R. Markovina \\ Department of Naval Architecture, Faculty of Electrical Engineering, \\ Mechanical Engineering and Naval Architecture, University of Split, \\ Croatia
}

\begin{abstract}
This paper presents a historical review of work organisation, wooden materials, tools and devices used in shipbuilding in Korčula (an island in south Croatia, where Croatian shipbuilding was born), as well as the bases of manual preparation of timber built boats and ships of Korčula in the past, some of which are still used today.

Keywords: historical review, wooden material, tools, Korčula's wooden shipbuilding.
\end{abstract}

\section{Introduction}

As is well known today, the island of Korčula is situated in the southern part of the Croatian Adriatic coast. It had, in the past, several different types of forests required for good wooden materials, especially pines, holm-oaks, mulberries, carobs and Mediterranean hackberry of which each type had its own role in the building of ships and boats. The clauses in the Statute of the island and town of Korčula from 1214 speak about the importance of these forests, whose cutting and export was strongly and strictly regulated.

The building of a boat was inspected by its owner, who was at the same time the chief-shipbuilder. Depending on the type and purpose of the boat and its dimensions, the saw men prepared all wooden parts, in consistence with the ship's proportions. Each of these wooden parts was prepared according to the chief-shipbuilder's specification, using precisely defined tools. 


\section{A short review of work organisation and basic building procedures in Korčula's wooden shipyards}

It is known that a good work organisation and preparation is only "half of the work". That is the reason why the owners devoted a great attention to this phase of production. The work organisation was executed as follows:

1. Purchasing of all material (timber, outfit, tools and devices)

2. Cutting and sawing logs, according to one's own technology, and preparing boards for each type of construction parts,

3. Determining the main dimensions according to experience, taking into account its relationships (as L/B about 3, depending on the type of boat),

4. Determining the breadth of the keel (as "for each meter of boat length take one centimetre of keel breadth),

5. Determining other principal dimensions for each construction and form parts by a special "mezzaluna - buška" system of construction,

6. Preparation of a working area and positioning the bar keel, as the base for boat building, dividing it by 20 theoretical frames, with a stem and stern frames, and positioning a few real frames on bow and stern,

7. Determining the deck line, and positioning the top shell plates, (the last from the keel), and after that, positioning the inside bottom floors (with the distance of about 20 to $25 \mathrm{~cm}$, which is the frame spacing), and the opposite top shell plates,

8. Positioning other frames from the middle to the stem and stern,

9. Controlling the horizontal and vertical position of all built parts and fixing them,

10. Positioning other shell plates, from the top shell plate to the keel, and closing the stern part of the boat, with all prepared parts, including stern seats, benches etc., and marking the deck bow and stern deck line, and positioning of the under-deck construction (stringer plates, beams, side deck plates, etc),

11. Positioning other prepared construction parts on the bow, and scheduled outfit,

12. Positioning small outfit parts on all parts of the boat (thole pins, side bars, davits, etc),

13. Positioning of the mast fundament clamp and other mast stiffened parts, (if necessary)

14. After the remaining parts are built in the boat the caulking starts, plastering with stucco on the top, to assure water-tightness, and the whole boat is polished and cleaned from possible outgrowths, to be prepared for painting,

15. The painting is realised as follows:
- $\quad$ the first coat,
- $\quad$ the second coat up to the waterline,
- $\quad$ the third coat under waterline by antifouling paints.

In the past the boats were painted by tar. 

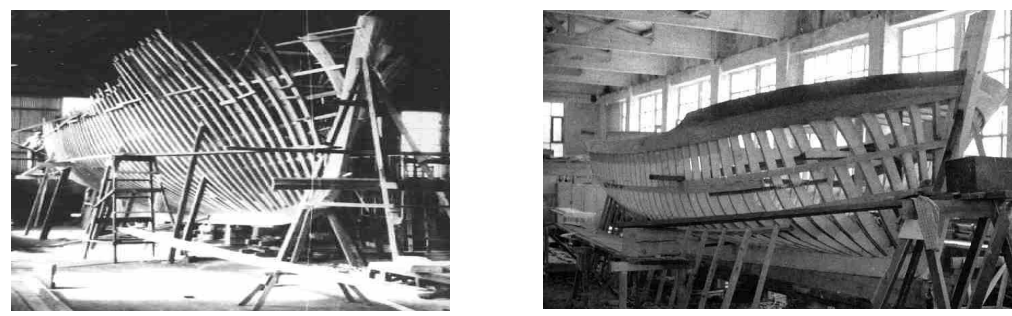

Figure 1: The Korčula's fishing boat during construction.

The work organisation, work preparation and especially building technology were a very carefully kept secret, and were transferred from one generation of shipbuilder to another.

The boat's building was organized, from the beginning to the end by the "master", the main shipbuilder - in most cases the owner of the shipyard. He signed the contracts, ordered the material, designed and constructed the boats, controlled the quality of building units and was the hardest worker. He kept all information in his mind and in that way he protected his manner of building.

The main characteristic of all workers in a small shipyard was the loyalty to the main shipbuilder, shipyard and work, order, self-abnegation and respect to the all employers. All the jobs were agreed by the pledged word with small sketches, because the pledged word of the owners was more potent than all the written signed documents. Just at the beginning of the XVI century the agreement of the boat building was realised by the signed contract, if the ship owner worked with that particular shipyard for the first time (figure 2).

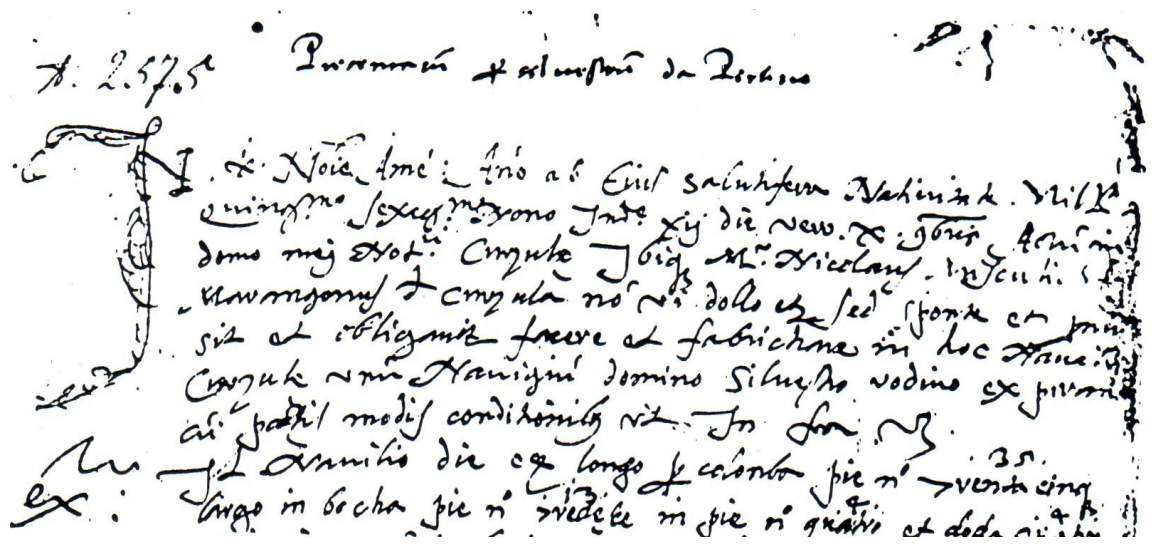

Figure 2: $\quad$ The beginning of a Shipbuilding contract from XVI century [8].

The small shipyard for the production of wooden boats was strictly separated at the area: storehouse of the material and templates, storehouse for tools, a sawmill, a wood-processing shop, an area for frames and plates curving (fine 


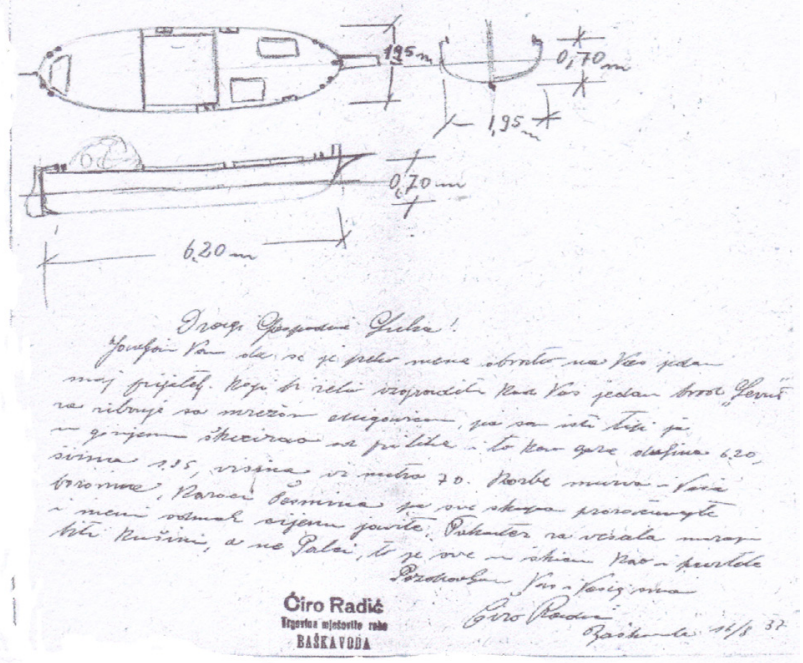

Figure 3: The letter of intention for boat building sent in 1937 to the Depolo family - Korčula [8].
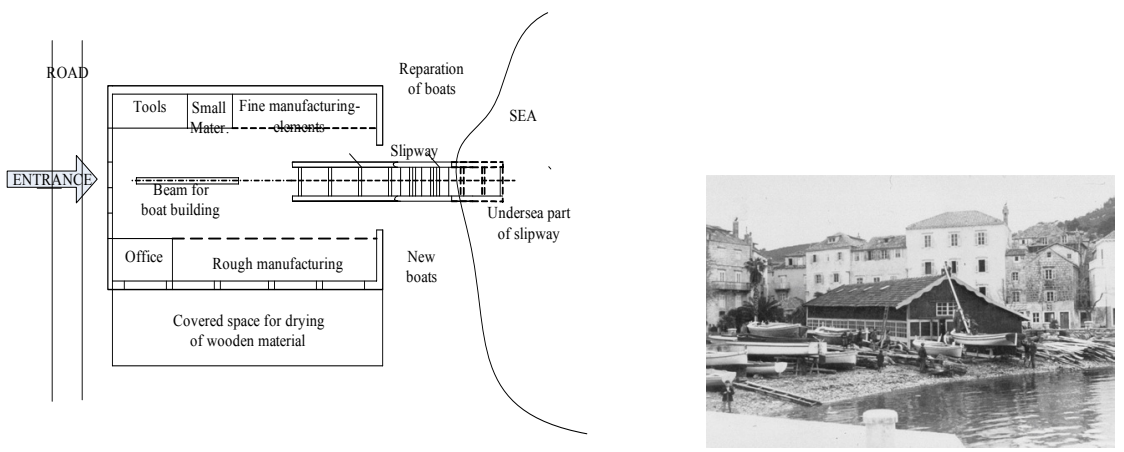

Figure 4: The small shipyard's layout and photos of the old "St. Nicolas" shipyard in Korčula - Croatia from XIX century.

manufacturing and rough manufacturing), an area for the boats building (slipway), space for wooden material drying, office etc. The shipyard was covered and called "baraka", as presented in figure 4, in which the general rule was " put all objects in their proper place", at the reason not to loose the working time, because the "master's word was the word to the delivery date.

\section{The types of timber used for construction parts and its preparation}

The timber, as the principal material for building the ships, had to be healthy, chosen and cut at the right time (mid-January or end of August) when there was 
not much sap in the tree, to avoid rotting and parasites. The sawed logs were purchased for all year works, without bark. When they were transported to a shipyard, they were put and fastened on a sawhorse and were sawed to the needed thickness, depending on the purpose, by a big saw. The sawing was usually carried out by odd numbers of iron cutters on it, to obtain even numbers of boards for shell plates. After sawing, the cleaning from sawdust (cause of its humidity) was obligatory and the boards were put in order vertically or horizontally, one above the other, with the thin laths between the rows to assure ventilation, and fastened drying.

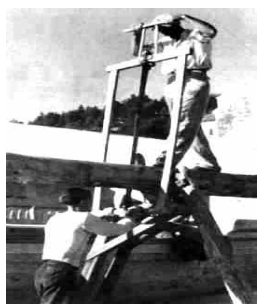

Figure 5: Logs sawing up.

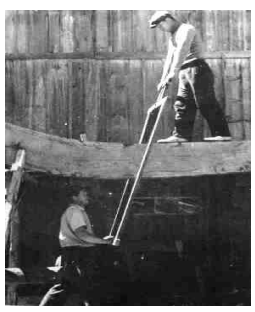

Figure 6: Logs sawing down.

The fig and Mediterranean hackberry logs were sunken into the sea for about two months, in order to lose acid and natural humidity, and after that the sawing could start. For the boards used to build frames, the preparation was done following the same procedure, but, to prevent deformation, these boards were pressed by weights.

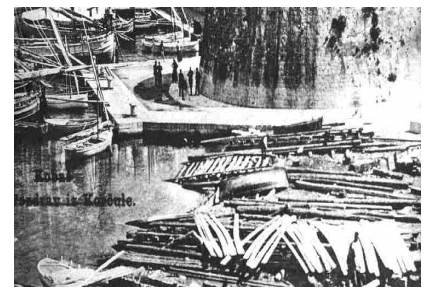

Figure 7: Horizontal drying of plates.

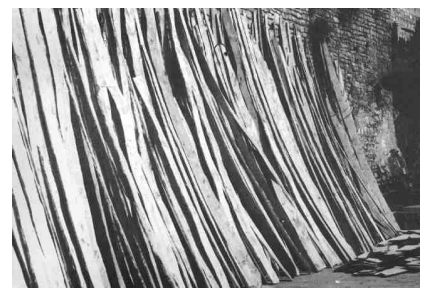

Figure 8: Vertical drying of plates.

In spite of great quantities of the raw material available, the Korčula shipbuilders imported timber; pine from the neighbouring islands of Mljet and Lastovo, holm-oak from either the peninsula of Pelješac or Bosnia and Herzegovina, and the mast timber from Croatian Littoral, a central part of Croatia, or from Montenegro.

Only a small part of construction materials were obtained directly by sawing or carpentering, such as massive ones (keel, stem and stern frame, connection part between keel and stem) or very small ones (tiller, thole pins, davits, deck opening stringers, benches etc.). But other parts, which had a boat form (opposite 
frame, first shell plate, opposite first shell plate, inner bottom side plate, margin plate etc.) had to be additionally curved if the natural material did not have a satisfactory form. These especially concerned frames, whose curving was, regarding the strength and thickness of wood, more challenging than curving the shell plates.

Korčula's shipbuilders, until the XIXth century, imported all ship equipment, but later they produced them by themselves, or imported them from nearby districts.

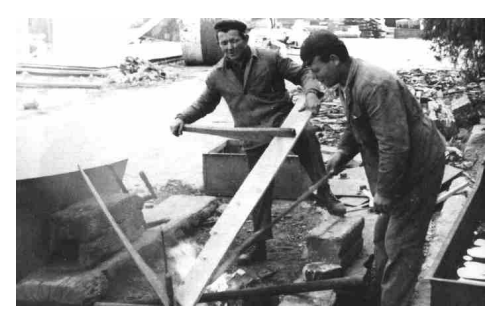

Figure 9: Manual forming (curving) of the shell plate.

Very famous Croatian, especially Korčula timber for shipbuilding was:

- $\quad$ Pine (Pinus halapensis), with a very good flexibility and strength if it was sawed at a special year's period and if it passed all necessary preparations.

- Holm-oak (Quercus illex), a special kind of oak, very massive, very hard and very strong,

- Mulberry (Morus), very strong and highly resistant,

- Elm (Ulmus minor)- and ash (Fraximus ormus) as middle hard and tough wood, was used usually for masts and rigs, and

- $\quad$ Other types of timber like: oak, beech (Fagus sylvatica), Mediterranean hackberry (Celtis australis), fig (Ficus carica), carob ( Siliqua) and mahogany for boat interiors.

The characteristic constructed parts were built from the following type of wood in Korčula's shipbuilding:

- keel: from oak or holm-oak. (The specific problem of holm-oak was great hardness, and it was very difficult to work out, and its very strong acid had a corrosive effect on screws and nails, if it was not sunken into the sea for some period of time),

- stem and stern frame: from oak, holm-oak, elm or ash,

- opposite stem and opposite stern frame: elm, mulberry and carob,

- frames: from elm, oak or ash, but earlier was used also mulberry, carob, Mediterranean hackberry or fig,

- $\quad$ shell plates and stringer plates (bulwark rail): domiciles pines, larch or oak,

- transom plates: from domiciles pines, mulberry or elm, but today mahogany,

- deck beams: from domicile pines, elm, oak, juniper, 
- bow deck: from planks of juniper, elm, pine, larch, but today mahogany or teakwood,

- benches: from domicile pines, elm, oak or ash,

- stern seats: from fir-timber,

- rudder: from domicile pines,

- oars: from beech, ash, sometimes domicile or Bosnian pines,

- motor base: from oak,

- stringers: from oak, pine, juniper,

- stiffeners: from oak or elm,

- planking: from oak, pine, larch,

- bulkheads: from juniper or plywood,

- superstructure: from oak ash, pine, plywood,

- furniture: from plating of walnut, cherry, maple, ash and

- nailing: from zinc coated nails, copper rivets and bras screws.

\section{The basic tools and devices in Korčula's wooden boat building with local glossary}

The most important and common used tools and devices, used by shipbuilders for the preparation and shaping timber, are shown in the following figures:

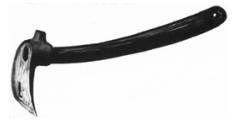

Figure 10: "Ašeta".

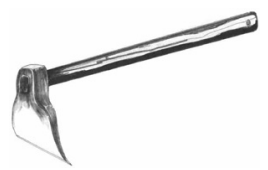

Figure 11: "Ašun".

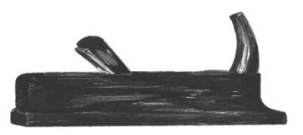

Figure 12: The plane.
AŠETA (AŠSA, TESLICA): the tool for taking down the timber by one hand, until some defined dimension. After "ašeta" the boards were treated by "ašun"

"AŠUN": the big "ašeta", for treating bigger and hard wooden parts. The woodworking was performed by standing with both hands, and after treatment by "ašun", the boards were sawed.

THE PLANE ("PLANJA"): for treatment of timber surface. There are various types: rabbet plane, trying plane and scrub plane with one or two plane iron, for convex / concave surfaces. 


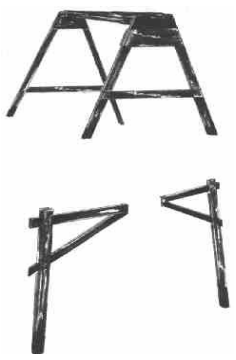

SMALL SAWHORSE ("KAVALET"): wooden construction for positioning and fixing the boards before cutting, and used on the slipway as wooden support.

"FORKETA" ("ŽBULTA"): wooden tool in two pieces, for supporting the boards at the other second end, because the first end is supported by "kavalet".

Figure 13: "Kavalet" and "Forketa".

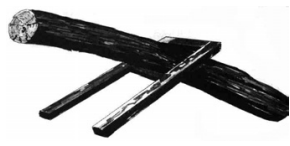

Figure 14: "Rasoha".

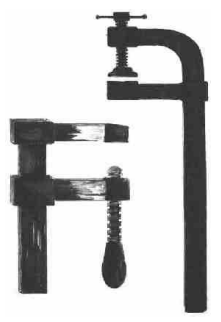

Figure 15: "Morša".

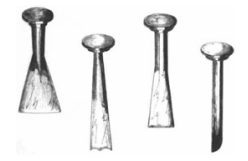

Figure 16: "Padela".

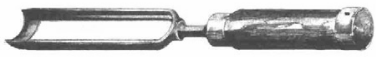

Figure 17: "Pedun".

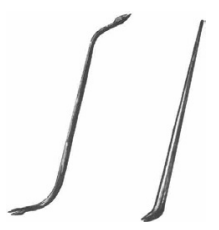

Figure 18: "Manavela".
"RASOHA": wooden construction like "A" letter was used for supporting a court boards during sawing.

"MORŠA": wooden or steel tools to press the court parts, before sawing, especially for curved plates, for frames.

"PADELA": iron chisels for putting the hemp fiber - caulking, sharpened at the lower part with several dents and rounded on top for hammering.

"PEDUN": a large iron chisel used for patching the hole in wooden parts.

"MANAVELA": the crow-bar used to pull out nails, hammered in the wooden construction. 


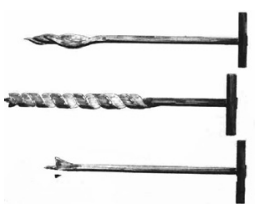

Figure 19: "Trapan".

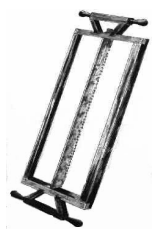

Figure 20: Two-handed saw.

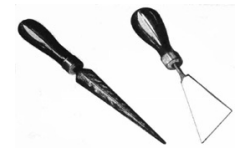

Figure 21: Flat - file.

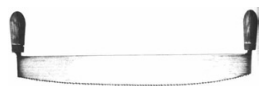

Figure 22: Hacksaw.

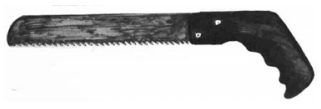

Figure 23: Hand-saw.

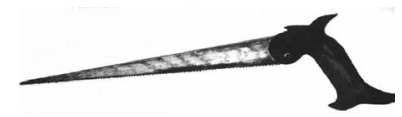

Figure 24: Sharpened hand-saw.

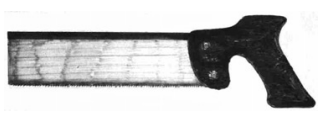

Figure 25: Small-tooth saw.
"TRAPAN": bore (auger) used for drilling a strait hole into wooden parts.

"TWO-HANDED SAW": used for sawing the boards. In the middle of wooden construction, an iron toothed plate is placed. Two workers used it at the same time.

FLAT-FILE ("TRIJANGUL"): for saw sharpening, triangle shape - flat-file.

HACKSAW ("ŠEGUN"): made by special steel with a big tooth and two handles at the ends, used for sawing boards before other treatments (two-handed saw).

HAND-SAW ("ŠEGAC"): the one-handed saw used for sawing small pieces with one handle at one side.

SHARPENED HAND-SAW"("ŠEGAC OD PUNTE"): the hand-saw at one end about 4-6 $\mathrm{cm}$ big, and at the second end about $0,5 \mathrm{~cm}$ big is used for opening the hole on wooden parts.

SMALL-TOOTH SAW ("PEŠTARIOLA"): the hand-saw with one end handle is used for sawing fine and thin parts. 


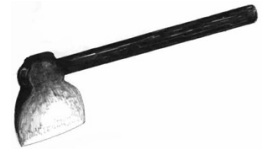

Figure 26: Little axe.

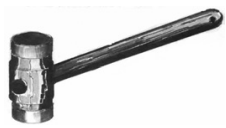

Figure 27: Mallet.

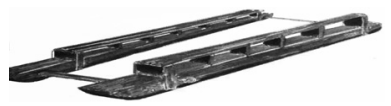

Figure 28: Ground ways.

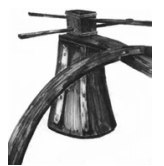

LITTLE AXE ("SIKIRA"): used for cutting a timber into small parts.

MALLET ("MACOLA"): wooden hammer for caulking boat's plates or decks. Ends were rounded and iron-bounded in order not to be crushed during the work.

GROUND WAYS ("VAŽI"): wooden part of the slipway on which the ship was placed before launching.

MANUAL WINCH ("ARGAN"): the device for pulling the boats on the slipway.

Figure 29: Manual winch.
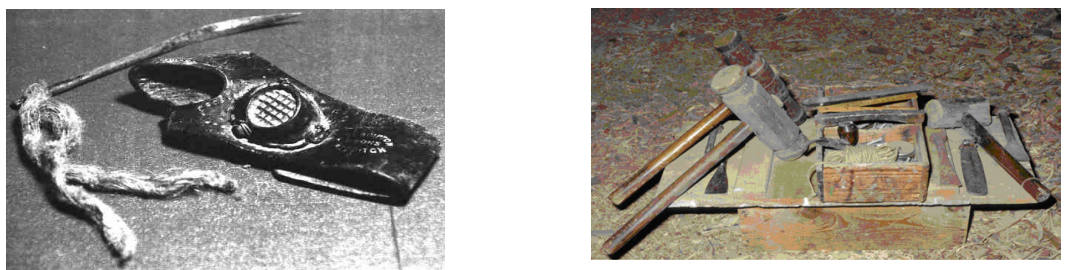

Figure 30: Tools for sail production. Figure 31: Saved tools the Depolo familyKorčula, Croatia.
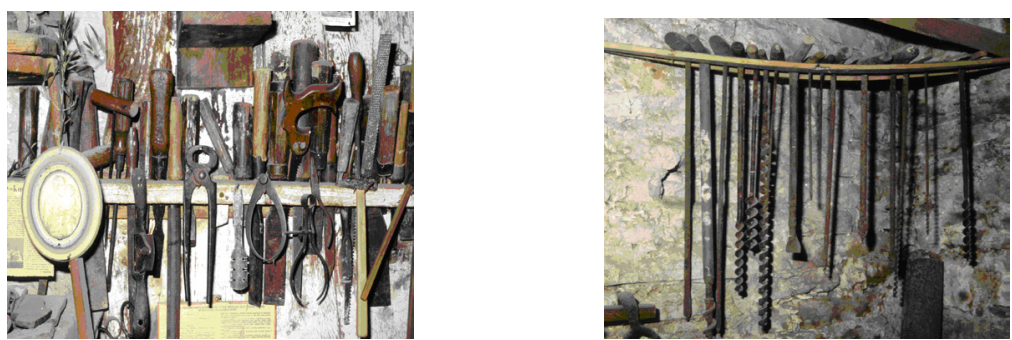

Figure 32: Saved shipbuilders tools the Depolo family - Korčula, Croatia. 


\section{Conclusion}

The main characteristics of Korčula's shipbuilders which have given them a very high place in wooden shipbuilding all over the world are a great building experience, long tradition and especial method of construction, named "mezzaluna" ("buška"), which was a great secret, transferred from one generation to another, using good useful tools and various types of construction material.

Special methods of design and construction for a type of small boats (fishing and merchant boats), especially for bow and stern forms, were a typical sign of a whole shipbuilders' family, and it was very difficult, practically impossible, to obtain these secrets.

The owner of a shipyard was the main constructor, technician, designer and head of production, and he knew at the very beginning, at the time of contracting, the final shape of the boat. He took part in the building of the boat from the contract until it was delivered. But, he was, first of all, the teacher.

Somebody asked a question what is so special about Korčula school of wooden shipbuilding and its boats. The answer is very simple: "They were not the boats - they were the soul of the master, dressed in floating wooden construction". That is the real answer, and that is the unique secret.

\section{References}

[1] D. Kalogjera: Korčula's shipbuilding, Prometej, Zagreb, 1998.

[2] V. Foretić: About historical Korčula's shipbuilding data, "Pomorstvo II", Rijeka, 1947.

[3] J. Fazinić: The history of Korčula's shipbuilding, "Jadranski dnevnik" No.24, Split, 1936.

[4] J. Sladović: "How the boat in Korčula is built", "Zbornik otoka Korčule", Korčula, 1970.

[5] From the taped conversation 2003. with old Korčula's shipbuilders: Davor Kondenar (died in 2004.), Darko Tasovac (died in 2005.) and the youngest Igor Čulić,.

[6] R. Markovina: From the authorized lectures of "Croatian Maritime Heritage" at Mechanical engineering scientific postgraduate studies, University of Split, Faculty of Electrical Engineering, Mechanical Engineering and Naval Architecture, 2003.

[7] From the archive of known shipbuilders Depolo- family, Korčula - Croatia.

[8] Internet: Typology of boats and ships (www.ctk-rijeka.hr), Society of shipmodels workers "Leut", (www.leut-krk.hr). 